\title{
Capital Accumulation, the Role of the State and Human Rights in Argentina: Contributions for debates on economic and social right
}

OÑATI SOCIO-LEGAL SERIES, VOLUME 10, ISSUE 4 (2020), 717-743: INVESTIGATIONS -

INVESTIGACIONES - IKERLANAK

DOI LINK: HTTPS://DOI.ORG/10.35295/OSLS.IISL/0000-0000-0000-1119

RECEIVED 10 JUNE 2019, ACCEPTED 16 DECEMBER 2019

\section{MAURO CRISTECHE* (iD)}

\section{Abstract}

This work aims to contribute to the debate on the role of the State and the Economic and Social Rights in Argentina from the analysis of the capital accumulation process and the structural changes that have taken place in the country in recent decades. First, we define the work within the debates on the role of the State and economic and social rights. At the core of the work, we present our own contribution, based on our previous research and other authors' works. First, we highlight some transformations on the capital accumulation process in Argentina. Then we analyze the role of the State through some of the most important social policies in the last years but we also add the consideration of some government's regulatory, fiscal, monetary, and labor-market policies. Finally, we develop our interpretation about the role of the State on the fulfillment of economic and social rights in the last decades.

\section{Key words}

Capital accumulation; role of the State; human rights; Argentina

\section{Resumen}

Este trabajo pretende contribuir al debate sobre los derechos económicos y sociales y el rol del Estado en Argentina a partir del análisis del proceso de acumulación de capital y los cambios estructurales que han tenido lugar en el país en las últimas décadas. Al comienzo encuadramos el trabajo en los debates actuales sobre el papel del Estado y los derechos económicos y sociales, y luego presentamos nuestra contribución, basada en desarrollos propios y en trabajos de otros autores. Primero destacamos algunas transformaciones en el proceso de acumulación de capital en Argentina. Luego analizamos el papel del Estado a través de algunas de las políticas sociales más

* CONICET Full Assistant Researcher, Argentina. Constitutional Law Assistant Professor and Instituto de Cultura Jurídica Researcher, Universidad Nacional de La Plata. O’Brien Fellow in Residence. Centre for Human Rights and Legal Pluralism, McGill University, Faculty of Law, Canada. Contact details: 58248 Street, $3^{\text {rd }}$ floor. La Plata (1900). Email address: maurocristeche@yahoo.com.ar 
importantes de los últimos años, pero también consideramos otras políticas como las regulatorias, fiscales, monetarias y del mercado laboral. Finalmente, desarrollamos nuestra interpretación sobre el papel del Estado en la satisfacción de los derechos económicos y sociales en las últimas décadas.

Palabras clave

Acumulación de capital; rol del Estado; derechos humanos; Argentina 


\section{Table of contents}

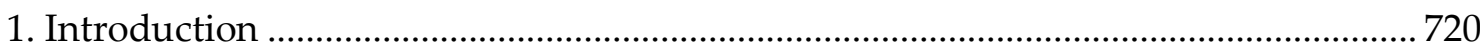

2. Debates on Economic and Social Rights and the Role of the State.............................. 721

3. Capital Accumulation, Public Policies, and Human Rights in Argentina .................. 724

4. Analyzing huge welfare policies: Moratorias Previsionales

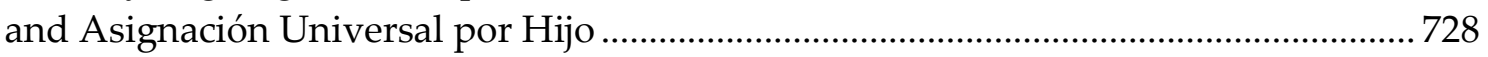

5. The role of the State and Economic and Social Rights precariousness........................ 732

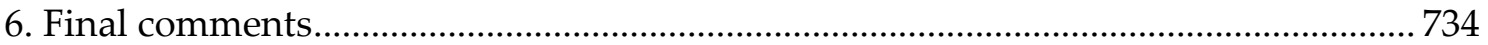

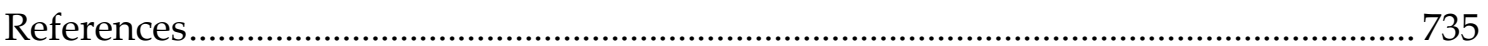




\section{Introduction}

The debates on the role of the State and economic and social rights (ESR) have grown and have been renewed in recent years in Argentina. The context of the debates is still that of fragmented and inequitable society, with high levels of living conditions precariousness and structural inequality. However, in the first decade of the $21^{\text {st }}$ century an expansive cycle of capital accumulation which developed in Argentina - as in other Latin American countries - allowed a considerable recovery of employment, expansion of welfare policies and improvement of social indicators (Salvia and Lindenboim 2015). This fact led to the flowering of apologetic discourses of the "presence of the State" (Álvarez and Bonnet 2017), that placed the "human rights" of "vulnerable sectors" at the forefront of their rhetoric. Thus, a broad consensus on the positive value of social policies was built, but more particularly on welfare policies aimed at the most impoverished sectors under the paradigm of a development model but with inclusion and social justice. These kinds of discourses were strongly propagated throughout the Kirchner government (2003-2015) in Argentina (Bossert 2016), and other similar Latin-American experiences, such as Brazil, Ecuador, Venezuela, and Bolivia.

On the other hand, the expansion of State intervention has been considered one of the main characteristics of "populist" governments (Ferreres 2011, Damill et al. 2015), criticized by confusing policies which are unsustainable in tandem with the economic well-being, and by wasting the wealth of the prosperous years on policies that leave no favorable results in the long term (Cachanosky 2017).

Despite its "unpopular" policies toward the working class, particularly expressed on salaries contraction and the impact of the local currency devaluation on living conditions, the right-wing government that took over in the period 2015-2019 kept the discourse based on human rights as a political resource, and welfare policies for the poorest sectors continued to expand, some of them supported by multilateral agencies, such as the IMF.

In the legal field, many approaches have insisted on the strength of constitutional mandates which impose obligations and responsibilities on the States, and have remarked the "outstanding debts" as a strategy to demand public policies that are better designed under constitutional standards, and the political will to carry them forward through budget items. Moreover, Human Rights-Based Approaches (HRBAs) to public policies have become a very influential stance to analyze the role of the State to protect and satisfy economic and social rights (ESR), focusing on the analysis of protection policies for the most vulnerable sectors, and welfare policies to guarantee basic social services.

However, HRBAs have paid less attention to welfare state functions linked to macroeconomic regulations, to the labor market and to the sale conditions of the labor force, which are essential for a comprehensive understanding of the role of the State. Instead, critical analyses that emphasize Argentina's social structure characteristics and the limits imposed by the accumulation of capital to fulfill ESC are scarce.

In this paper we intend to intervene in the complex debate on social policies and ESR in Argentina, seeking to contribute to the understanding of how the needs of the capital accumulation process condition the role of the State and the content of rights, and why 
it is necessary to analyze them in relation with economic contexts. Taking into account the Esping-Andersen's (1990) classical conception of welfare state, we shall relate its functions and its contradictory development in the last decades. We will go beyond the redistributive role of the State through social policies by adding the consideration of the welfare state conception that highlights the government's regulatory, fiscal, monetary, and labor-market policies (Garland 2016), and we shall point out that it was the evolution of the labor market that has become particularly crucial to better understand the role of the State and the shapes that welfare policies have taken in the last decades.

We shall start by presenting some perspectives and debates on the fulfillment of economic and social rights, showing a special interest in HRBAs that focus on State responsibilities beyond the analysis of the economic reality. Then we will develop our own contribution, considering various characteristic elements of the Argentinian capital accumulation process from the 70's to the present, such as transformations produced in the labor market and their impact on the living conditions, the growing intervention of the State expressed in terms of public spending and taxation, and expansion of some welfare policies. Then, we will summarize two of the most important public policies in the last years, such as the Social Security Moratorium (Moratorias Previsionales) and the Universal Child Allowance (Asignación Universal por Hijo), and then we shall offer a possible explanation on the expansion and new shapes of welfare policies and their link with the labor market.

Our approach to the transformations of the Argentinian capital accumulation process in the last decades is based on our own research but also on several works developed by other authors (Iñigo Carrera 2007, 2017, Peralta Ramos 2007, Graña 2015, 2018, Salvia and Lindenboim 2015, Kennedy 2015, Caligaris 2017, Seiffer and Rivas 2017, among others). The increasing intervention of the State has also been explored by other authors (Grassi 2003, Falappa and Andrenacci 2009, Isuani 2010, Seiffer 2015, among others), although from very diverse perspectives. However, the link between both the transformations in the capital accumulation process and the expansion of the State has not been examined deeply enough and is much less common in the Human Rights field to apply it to contemporary Argentina.

The main purpose of this work is to contribute to studies on the role of the State and economic and social rights in Argentina by proposing an analysis of the State capacities to fulfill ESR based on the evolution of the capital accumulation process and the labor market.

\section{Debates on Economic and Social Rights and the Role of the State.}

The literature and debates around the role of the State, social policies and human rights are very rich. Although a deep analysis of them is not the subject of the paper, here we would like to simply go over Human Rights Based Approaches (HRBAs) associated with the goal of analyzing the problematic relationship between the accumulation of capital, the role of the State and economic and social rights, and as a way to start to better develop our own contribution.

Since the seventies, economic, social and cultural rights (ESCR) have drawn the special attention of Human Rights organizations, promoters and theoretical currents (Moyn 2012), while the language of rights acquired tremendous symbolic value worldwide 
(Joshi 2009). Beyond this international context, what has been quite evident in Argentina in the last two decades was the growth of HRBAs. All this within a context of a fast recovery of the economy after the worst economic and political crisis in the Argentinian history in 2001 - and the fresh memories of extreme poverty levels and inequality as a result of that. References to terms such as social justice, inclusion, and extension of human rights were made much more often, and these aspirations were particularly linked to the responsibilities of the State. As the State was placed as the guarantor and inexcusable responsible for the effective exercise of Human Rights, demands toward the State were extended. ${ }^{1}$ Thus human rights, welfare policies and the role of the State were coming together in a more transcendental debate.

The legal field and particularly the Constitutional Law area have strongly been impregnated by HRBAs. What in Argentina has been called "enfoque de derechos" (HRBAs) has been defined by its promoters as a "methodology", a set of interpretive standards within the scope of human rights that must be necessarily incorporated in public policies in general, and in social policies in particular, in order to comply with the mandates but also to protect the guarantees contained in each right (Pautassi 2010). According to them, HRBAs demand transformations in the state structure to help States fulfill their obligations by implementing "integral policies" under the mandates incorporated in the Constitutions and International Treaties (Pautassi 2015), the empowerment of policy recipients by recognizing that they are right holders that generate obligations to the State (Abramovich 2006), and discuss "economic models that are respectful of human rights" (Pautassi and Gamallo 2012).

HRBAs have produced contributions of descriptive value, data systematization, and interdisciplinary analysis regarding broad themes such as the features of inequitable societies and insufficient public policies. They have contributed to put some important topics, such as gender issues in economic and social rights, housing, or access to basic services on the legal agenda, and have also proved useful tools to judicial activism in several battles to promote human rights. Eventually, they have meant an overcoming of the traditional views of constitutional law, which explore human rights and State responsibilities prioritizing the dogmatic analysis and omitting multiple antagonisms that rights present in daily life and their intimate link with economic reality.

HRBAs have also been criticized from different points of view, but criticism has mostly been theoretical. Kennedy (2002) has tried to synthesize those that come from Critical Legal Studies. Other authors such as Kennedy (2007), O'Connell (2017) or Moyn (2018) have also argued against the contemporary wave of exaltation of human rights (Moyn calls it "the last utopia"), because it would be something like a distracting factor carrying the energy that must be directed towards the demand for more egalitarian economic

\footnotetext{
${ }^{1}$ We can find here a substantial difference between the old liberal doctrine of human rights that emerged with the French Revolution and that which was expressed as a result of the proliferation of the International Human Rights Treaties. Both iusnaturalist philosophies, the first acknowledged equality before the law and ownership of all rights by the mere condition of persons, but within the framework of nascent capitalism in which the market would be the guarantor of compliance, while for the State reserved minimal powers-the administration of justice, security. Throughout the twentieth century, material equality and the universality and operability of all rights were recognized. This process was particularly relevant on ESCR field, and the role of the State in its implementation (Behm and Cristeche 2017).
} 
reforms, while economically regressive programs are imposed around the world (Moyn 2018).

However, in Argentina the HRBAs have attracted much more supporters than critics (Pautassi 2015), and it is not easy to find specific critics to their main cornerstones. One of the exceptions is Grosman (2008), who claims for a "more realistic approach" to think about state responsibilities on human rights satisfaction, pointing out that "in a context of allocation of scarce resources" the existence of a necessity is an essential condition, which is not enough to ensure the satisfaction of rights. Grosman adds that any social right that cannot have a real and concrete benefit can therefore not be an institutional mechanism, and he goes beyond the classic book The Cost of Rights (Holmes and Sunstein 2000), which differentiates the rights "of paper" with the rights "with teeth", making reference to the fact that when a right is recognized there must be a budget that allows to make it effective, and contrarily, without a budget the right is worth "not even the paper where it was written". In the face of the HRBAs that claim for "integral policies" regardless of the economic context, according to Grosman scarcity poses a structural problem that must be analyzed frontally by those who take decisions in this respect, and we should ask about the cost that can reasonably be faced by the State in a context in which different needs compete against one another for scarce public funds.

Arguments as "scarcity" or "rights competing against one another" are not uncommon in the legal arena and have usually been used by the Justice and governments against Human Rights claims (Asociación Civil por la Igualdad y la Justicia - ACIJ - 2018). ${ }^{2}$ Although the argument for demanding the consideration of the economic context when thinking about the limits of state responses is partially valid, the "scarcity of resources" is not a good starting point to analyze these limits. We shouldn't forget that the main reason for the world economic crisis is super production or, in the case of Argentina, the fact that the country has the capacity to feed 400 million people and more than $20 \%$ of its population is poorly fed, ${ }^{3}$ or more than $16 \%$ of the 2019 public budget has been used to pay interest on the external debt, which is more than the annual amount that the State spends on public employees' salaries and six times the cost for the 4 million beneficiaries of Universal Child Allowances.

From our point of view, HRBAs have focused on the intervention of the state in its "redistributive" role through social policies, especially those protection policies for the most vulnerable sectors, without paying enough attention to the evolution of the Argentinian capital accumulation process. They have been claiming that the State does not fulfill its conventional obligations and fails in its duty to protect human rights, but without asking for reasons beyond the political will, and therefore establishing a relationship of externality between state capacities and the capital accumulation process.

Garland (2016) points out that this "conception" of the welfare state, which highlights its role in the economy, is the broadest outline and the least familiar in public debate.

\footnotetext{
2 What is paradoxical is that HRBAs themselves have sometimes adopted the idea of "context of scarcity" (e.g. Giménez Mercado and Valente Adarme 2010, Arcidiácono and Gamallo 2011).

${ }^{3}$ As Moro (2011) has pointed out, the well-known contradiction of living in a leader in food production country and in parallel that there is a situation of hunger in a very important portion of Argentine society, is rather apparent than real, since access to food does not really depend of the availability of food, but of the social position of the actors and their solvency capacity.
} 
We would add that the same happens in the legal field, although it is a concept more usual among economists and sociologists. Critical perspectives in social policies have been more consistent with framing public policies within the process of capital accumulation (Cortés and Marshall 1991, Netto 1992, Iamamoto 1997, Danani 2004, Grassi and Danani 2009). They treat social policies as specific social interventions of the State directly oriented towards the conditions of life and reproduction of life in different sectors and social groups, which operate especially upon the secondary distribution of income (Danani 2004), and which embody a specific shape of the capitalist social relationship (Seiffer 2015). The classic work by Cortés and Marshall (1991) clarifies the role of "modeling the capital/labor relationship" of state intervention and social policies, always within the process of capital accumulation.

In summary, our view is that, at least in Argentina, productions in the legal field, including HRBAs, have not taken enough notice of the evolution of the capital accumulation process and the state macroeconomic functions, which we consider essential to better understand the role of the State on the fulfillment of human rights, everywhere but especially in Argentina, where, as we shall see, very important social transformations have taken place in the last decades. Below we shall try to move forward with the analysis of these transformations and some other elements that could help to explain the characteristics and limits of the role of the State.

\section{Capital Accumulation, Public Policies, and Human Rights in Argentina}

The Argentine process of capital accumulation developed in relatively good conditions along the first half of the twentieth century. Its levels of incomes were similar to those of rich countries, there were no serious problems with employment, and equality was substantially higher than in every country of the region. In fact, Argentina's income distribution, characterized by a large middle class and large groups with middle and higher educational attainment, was once proudly described as "European" - or more "European" than that of its regional partners, in any case (Alvaredo et al. 2018). But since the 70s the country has been facing deeper problems and frequent economic crises (Rapoport 2011), and its social structure has suffered deep transformations (Peralta Ramos 2007, Salvia and Lindenboim 2015). Then its economic and social rates have been getting closer to those of neighboring countries in a process that has been called "latinamericanization" of Argentina (Peralta Ramos and Waisman 1987/2018). As an expression of this, Argentina's minimum wage had historically been the highest in the region, translated into dollars; however, in 2017 it was exceeded by other countries and in 2019 it fell to the ninth place, only overcoming Venezuela (Fraschina 2019).

We point out that taking the evolution of the Argentinian capital accumulation process into account is an ineludible step to analyze the emergence of certain social policies, their role in that process and how they perform economic and social human rights. Thus in this section, we would like to briefly highlight the structural conditions of the Argentinian capital accumulation process in the last decades.

As a typical agro-exporting country, Argentina's agricultural production is carried out with high productivity, thanks to the presence of particularly favorable natural conditions and, like other Latin American countries, participates in the world market mainly as a supplier of raw materials (Caligaris 2017). The differential rent and the 
simple monopoly made possible through the agrarian export constitute a flow, towards the country, of social wealth generated by the valorization of the capitals in the importing countries (Iñigo Carrera 2017). On the other hand, industrial capitals have historically faced difficulties in developing internationally (A. Gaggero 2008, Graña 2015), but until the 1970s the power of the agrarian sector expressed on "farm income" had worked as a compensation mechanism for their weakness (Iñigo Carrera 2007, Kornblihtt et al. 2016).

In fact, from 1940 to 1974 an increase in the average salary of the total economy was registered leading to the improvement of living conditions and expectations of "social ascent" (Seiffer 2019) and there had been no serious problems of unemployment and underemployment. The Argentine society was characterized by relatively equal income distribution (Graña 2015), and specifically by the presence of a large fraction of workers with middle and high qualifications (Alvaredo et al. 2018). Then the increase in labor productivity worldwide in the 1970s led to a contraction in the agrarian income, and this contraction implied an abrupt contraction of the whole Argentine economy (Seiffer 2019). Since then, and being unable to increase labor productivity and industrial capacity, the capital accumulation process had to look at other sources of compensation valuation for its reproduction (Iñigo Carrera 2006, Kennedy 2014).

One of the sources of wealth to reproduce local capitals that strongly emerged in the mid-70s has been related to lowering labor costs downward in real wages (Graña 2015, 2018, Iñigo Carrera 2017, Cazón et al. 2017, Kennedy 2018). In 1975 the country was struck first by a hyperinflation (known as "Rodrigazo") and the next year by the bloody military dictatorship, which led to yet another abrupt drop in salary (a fall amounting to $40 \%$ ). Since then a large tendency towards worsening living conditions, segmentation, and fragmentation of the working class sprang, through a process of labor market precariousness (Bertranou et al. 2013, Kornblihtt et al. 2014, Cazón et al. 2017, Graña 2018). This has been expressed in unemployment (especially under the crises), underemployment and outsourcing in their different ways (Basualdo and Morales 2014) ${ }^{4}$ and a general drop in wages. Some contributions have shown that, as a result, during the 1990s and the first decade of the 21st century, the extraordinary surplus value resulting from the deterioration of real wages was more important than income from the agrarian land (Kennedy 2014, Cazón et al. 2017, Graña and Kennedy 2017, Iñigo Carrera 2017).

The main mechanisms to lower wages have been inflation (Kornblihtt et al. 2014), a distinct characteristic of the Argentinian economy in the last decades (Rapoport 2011), and the devaluation of the local currency (Kornblihtt and Dachevsky 2010). Beyond their causes -usually associated with the "external restriction" (Gaggero et al. 2014), both phenomena are within the sphere of state regulation (Rapoport 2011). They are involved in one of the Welfare State's conceptions that refer to its macroeconomic and labor market regulation functions (Garland 2016).

Both mechanisms have been particularly essential in periods of economic crises, which have been recurrent and have had a strong and negative impact on social indicators. In

${ }^{4}$ Indeed, the 2018 INDEC report showed that the most dynamic figure in the last years has been the "socialmono-tax" (created in 2004), that is workers with very low income who are forced to bear all the social burdens that employers should pay (Instituto Nacional de Estadísticas y Censo - INDEC - 2018). 
the last forty-five years, Argentina has suffered at least six big crises: 1975, 1982, 1989, 2001-2002, 2008-2009 and the current one (2016-to date). 1975 inaugurated the run-down process that we have been describing with a hyperinflation that caused a $37 \%$ drop in real wages. The crises of 1982 and 1989 (with another hyperinflation) were particularly serious in terms of the fall in real wages (17\% and 40\%, respectively), but 2001-2002 was the worst in Argentine history: besides the $22 \%$ drop in real wages, more than $25 \%$ of open unemployment, around $60 \%$ of labor informality, more than half of the population below the poverty line, and more than $15 \%$ living below indigence line, which was considered by CEPAL as an "endemic social catastrophe". The size of such drop (and the recovery from that crisis) was due to a key state measure: a great devaluation at the beginning of 2002 (Kornblihtt and Dachevsky 2010).

Between 2003 and 2008 Argentina had the best growth in its history and poverty rates recovered until 2012, but continued to showing figures as if they were obtained in the middle of a crisis (between 26 to 35\%). Besides the fastest and the highest external indebtedness in the Argentinian history, the current crisis has revealed itself in high levels of inflation (55\% in 2019) and one of the biggest devaluations of the local currency between 2016 and 2019, leading to a 18\% drop in real wages.

Beyond the state capacity to fulfill economic and social rights through welfare policies, the labor market still plays a decisive role in the workers' income and therefore their living conditions. As Bertranou and Casanova (2017) have said, labor precariousness constitutes an obstacle to the recognition of workers' rights and protection against social risks (workplace accidents, unemployment, and poverty among the elderly), and can also lead to low productivity levels and a limited capacity for business expansion. On a more aggregate level, labor informality has an impact on equity, efficiency, the State's ability to collect taxes, the reach of social security, productivity and growth (Salvia 2019).

In summary, the reduction of labor force costs through different ways came up as a source to reproduce the Argentinian capital accumulation process (Iñigo Carrera 2006, 2017, Graña and Kennedy 2017, Seiffer and Rivas Castro 2017, Kennedy 2018). This phenomenon, which has been developing for decades, is extremely important to better understand the role of the State, and its responses to fulfill economic and social rights. As it has been pointed out (Garriz et al. 2012, Salvia and Lindenboim 2015, Instituto para el Desarrollo Social Argentino - IDESA - 2018), the condition of poverty in Argentina has stopped to be an exclusive problem for those people who have difficulty in obtaining a job and it has started to affect active employees. Workers who have a job (even many of them in the formal sector of the economy) are poor. The last poverty report (December 2019) showed that around $40 \%$ of Argentinians stay below the poverty line; only $44 \%$ of the economically active population has access to formal employment, while $78.3 \%$ of informal employees do not have pension contributions (Salvia 2019).

Considering this context, it is quite difficult to imagine that the capital accumulation process needs to fulfill the rights of the population to the fullest through welfare policies given that even the reproduction of many actively working people below their needs is a condition for its own reproduction.

Moreover, there have been other transformations that complete this picture and that could help to better understand the role of the welfare State through the social regulation of economic action (Garland 2016). One important aspect has been external indebtedness 
(Iñigo Carrera 2006, 2017, Basualdo 2006, Kennedy and Sánchez 2019). It has worked as a current source to valorize local capitals over their own capacity during most of the last decades (together with internal indebtedness that began in the last 15 years), resulting in a chronic debt (close to 100\% of GDP in 2019, the highest in the region), as well as in the growth in the expenditure of "debt services" and an insolvent State. Debt has usually followed the cycles of accumulation, so when it is restricted there is more indebtedness, and when it expands there are more disbursements (Iñigo Carrera 2017). As we said earlier, in 2019 Argentina had to pay more than the equivalent to all public salaries and 6 times more than the AUH only in interests accrued on the debt, meaning $16 \%$ of the total public expenditure (Observatorio de Politicas Sociales 2019). It shows the magnitude of the "debt problem", which has hindered the expansive moments of accumulation (Iñigo Carrera 2017) and has contributed to exacerbate the chronic fiscal deficit, which is increasingly unsustainable (Ferreres 2011).

Another important transformation has been the expansion of the public expenditure, especially in the social area, that we shall analyze later in more detail. On the other side, overall taxation has grown as well, and the tax structure became more regressive and unbalanced. Argentinian tax pressure exceeds $30 \%$ of its GDP (7 points above the average for Latin America and only 4 points below the average for OECD countries) (OCDE et al. 2019), which makes the competition with other countries even more difficult, especially as it is an economy that evidences high levels of informality (CEPAL 2012). As J. Gaggero (2008) pointed out, until the first half of the 20th century Argentina was a country that showed a mature and progressive tax structure, showing more similarities with developed countries rather than "partly-developed" ones. Then the system started to become more based on indirect or consumption taxes. In recent years, the share of wealth and high-income taxes has decreased substantially, accounting for $38 \%$ of revenue in 2015 to only $30.7 \%$ in 2018 . Then consumption taxation increased, accounting for 46\% in 2015 to 55.3\% in 2018 (Proyecto Económico 2019). Therefore, regression means greater support of the tax structure by popular majorities affecting their living conditions even more (ACIJ 2018).

Within this panorama, social policies have importantly expanded in the last decades (Grassi 2003, Danani 2004, Seiffer 2015). In the '90s, large assistance programs appeared, covering hundreds of thousands and then millions of families, and some authors started talking about an "asistencialización" process (massification of social assistance) (Grassi 2003, Falappa and Andrenacci 2009). After the 2001-2002 crisis, social programs were strongly expanded, and even that expansion was maintained when unemployment began to decline (Seiffer 2015, Álvarez and Bonnet 2017). Furthermore, as we will see next, in the last decade the two largest welfare policies in the Argentinian history were implemented. In addition, public employment, which had been important in the eighties and went down in the nineties, grew close to 100\% since 2003: from around 2 million public employees to 3.9 million (Diéguez and Gasparin 2016).

Some authors have pointed out that the degradation of the labor market, and the expansion of welfare policies and public employment are strongly related to the expansion of a surplus population for capital accumulation needs (Faleiros 2000, Matusevicius and Seiffer 2010, Fernández 2015, among others), and have shown how social spending gains importance in the consumption of the working class with respect 
to salaries (Seiffer 2013, Cristeche 2013) and a transformation of social spending as an expression of indirect salary is consolidated: the welfare component of social policy towards workers who cannot sell their labor power or who do so in conditions that are not enough to support their family expands (Kornblihtt et al 2013).

In the last four decades, the political-institutional correlate of a process of absolute and relative growth of relative overpopulation for capital - and, in correlation, a process in which an incremental labor force inserted into the labor market is remunerated below its value - is a process of expansion of the welfare policy of the state. The progressive prominence of assistance is expressed in the absolute growth of the mass of public resources allocated to this social area, as well as in the advancement of the care component over the rest of the social policy units, mainly social insurance. In this way, the space is opened as a result of the transformations carried out at the level of the socioeconomic structure, for a welfare process that is part of a general reformulation of the social protection pattern, within the broader framework of the neoliberal redesign of the Argentine state during the last third of the 20th century. (Fernández 2015, 13)

The structural conditions under which state responses to the satisfaction of economic and social rights are deployed have not received enough attention in the legal field. From our view, considering the evolution of the capital accumulation process and key phenomenon such as the degradation of the labor market, the continued imbalance of macroeconomic variables, the growth of social inequalities and overpopulation, can help to better understand the real dimension of the role of the State through welfare policies and public employment, and their impact on ESCR. To further work in this direction, in the next sections we will take a closer look at the latest big social policies.

\section{Analyzing huge welfare policies: Moratorias Previsionales and Asignación Universal por Hijo}

In the first decade of the new millennium two big public policies were implemented in Argentina: Moratorias previsionales (Social Security Moratorium) and Asignación Universal por Hijo (Universal Child Allowance). Indeed, these have been two of the most important welfare policies from the last decades; and according to several authors Arcidiácono and Gamallo 2011, Alonso and Di Costa 2011, Mazzola 2014, Micha and Trombetta 2018, among others -, they inaugurated a new stage for social policies in our country: the "broad social protection" system, aimed for "unregistered" large sectors of population who were historically "out of the system".

Argentinian pension systems have historically followed the Bismarckian design that associates benefits with formal employment and family position (Arza 2009, Arza and Chahbenderian 2014, Cristeche and Muñoz 2019). This model began to show problems in the face of the broad levels of labor informality and the process of change in family structures. In fact, at the beginning of the new century, active contributors barely reached $50 \%$ of active workers (Centro de Investigación y Formación de la República Argentina - CIFRA - 2009, Barrientos 2012). Successive governments had tried to improve this situation through "labor laundering" campaigns, but with very few results. Adjusting the pension system to a labor market dominated by informality and low number of contributors seemed to be a quite evident necessity.

The sharp devaluation of the currency in 2002 (and the consequent falling wages) and the favorable international prices of commodities, particularly soybeans, allowed a rapid 
economic recovery and growth after the last crisis (Kornblihtt and Dachevsky 2010, Adriani 2011), especially in the period 2003-2008. The industry recovered, as well as employment (public and private) and real wages (Graña 2015, Bertranou and Casanova 2017), and there were five consecutive years of fiscal surplus for the first time in Argentinian history. This situation significantly improved the number of contributors to the pension system, from 4.8 million in 2002 to 8 million in 2008 (CIFRA 2009).

In short, this was the immediate context where the pension reform was launched, focused on extending the social coverage to a greater number of people who had been left out of the formal market (Arza and Chahbenderian 2014). This meant an important change of paradigm to the Argentinian pension system, which from its origins had an evident contributory nature (access to benefits granted was generally associated with insertion in the formal labor market and the corresponding payment of contributions).

The foregoing was done through the implementation of two Moratoria Programs (PM) that allowed many people who did not meet the legal requirements of contributions to access the rights they were seeking. The key plan was the Plan de inclusión provisional (Provisional Inclusion Plan), promoted in 2004/2005, which virtually eliminated tax requirements set forth by local legislation, greatly increasing the coverage of the system. In addition, it mainly benefited women by aiming at the incorporation of domestic workers who did not meet such requirements -helping to improve the enormous gender inequalities (Arza 2012, Grushka et al. 2017, Cristeche and Muñoz 2019).

Although the economy was still showing signs of improvement in 2008, the international economic crisis had started to show its effects in our country, while at the same time the government had not been able to keep collecting further taxes from the agrarian sector. In October 2008 there was the re-nationalization of the system (which until then was maintained under a mixed system with a greater weight of capitalization).

The second MP, Pensión Universal para el Adulto Mayor (Universal Pension for the Elderly), was launched after the change of government at the end of 2015, rather as a continuation of the previous one. Formally, retirements continued to depend on the work trajectory of the person -in addition to their age- and not on universal criteria, such as citizenship or residency.

The main aspect of the MP system is that it distinguishes between those retirees and pensioners who obtained the pension benefit with 30 years of contributions (without resorting to any moratorium to complete years of contributions), and those who retired resorting totally or partially to the MP, becoming "second class" pensioners who don't even receive the "minimum benefit" but $80 \%$ of it, and don't have full pension rights.

As a result of the MP the pension system has really expanded its coverage. In 2003, the Argentine social security system had close to 3.5 million beneficiaries, while at the end of 2019, the retired and pensioners added up to about 6 million, with the total beneficiaries reaching to almost 7 million (Cristeche and Muñoz 2019). Thus Argentina reached the highest retirement coverage rate in Latin America, with 9 out of 10 elderly people in retirement age receiving some kind of pension benefit. In 1996, only 69\% of the country's older adults were in this situation (Comisión Económica para América Latina y el Caribe - CEPAL - 2012). 
The coverage extension of the system has mainly been on the basis of less rights and especially lower retirement benefits, which have followed the wages' decrease. Indeed, in 2003 the percentage of retirees who received the minimum benefit was close to $30 \%$ and close to $55 \%$ for the average benefit, although the social security coverage reached $70 \%$ of people in the age of retirement. While in 2012 , coverage exceeded $90 \%, 72.5 \%$ of beneficiaries received the minimum benefit and only $7 \%$ the average one. And the NonContributory Pensions and the Universal Pension for the Elderly equal to $70 \%$ and $80 \%$ less than the minimum pension benefit.

The strategy seems to have been aimed at transforming the pension system into a basic retirement pension scheme. The latest reform seems to confirm and aggravate the situation from two points of view: on a practical level, by the way in which the pension's amount is established, and more generally, by its transformation into a benefit alien to the idea of pension law and in a certain way to social security. We would, therefore, be in the presence of a progressive transformation that implies, on the one hand, the universalization of a subsidy for old age in the style of welfare policies, and on the other the denaturalization of pensions as deferred wages.

The funding of the pension system has increasingly been supported by contributions from workers and indirect taxes that, in their majority, also fall on the working population. Using data from ANSES, the agency responsible for financing the program, an exhaustive study by Fernández (2015) has revealed that:

The results obtained show that the bourgeoisie contributes up to 19.5 percent of the total income of the ANSES, the petite-bourgeoisie up to 5.5 percent, while the formal salaried workers' contribution amounts to 52.0 percent. The rest of the categories, such as revenues derived from State's interest income contribute 4.2 percent and international credit agencies only 0.01 percent, while income that could not be classified make 18.7 percent of the total resources of the ANSES. (Fernández 2015, 15)

Finally, the system's sustainability is deeply questioned. On one hand, the direct contributors to the system are around 12 million to support almost 7 million beneficiaries (that is, there are 1.7 active workers for each retiree or pensioner, while specialists advise that the ratio between contributors and liabilities should be 3 or 4). On the other hand, employer contributions have been reduced over time, in addition to different exemption tax policies designed to "promote employment" which have made companies almost exempt from bearing the cost of the pension system. Thus, the need for pension reform resonates all the time. It is currently tied to the agreement with the IMF, who recommend raising the retirement age, reducing salaries and modifying special regimes.

Along with the MPs, the other most important welfare policy in Argentina's recent history has been the Asignación Universal por Hijo (AUH). The AUH has probably been the most debated policy in the Argentinian history and it has generated a huge number of academic productions. The program was created in 2009, by a decree of the then president Cristina Fernandez de Kirchner, extending the system of Family Allowances and social protection to the unemployed and sectors excluded from the formal labor 
market, constituting a strong non-contributory social security component (Arcidiácono and Gamallo 2011, Pautassi et al. 2014). ${ }^{5}$

Its implementation occurred in a special economic context that required raising consumption levels in a still-expanding domestic market, which at the same time had already begun to show signs of exhaustion with respect to the reconstruction of the formal labor market (Kornblihtt and Datchevsky 2010, Graña 2018).

According to the official site of ANSES, the AUH covers about 1.9 million families (almost $16 \%$ of households), and 4 million children ( $49 \%$ of girls, $51 \%$ of boys). ${ }^{6} 43.6 \%$ of beneficiaries of the AUH correspond to the employed population, 50.5\% to inactive workers and $5.9 \%$ to the unemployed. Regarding "inactive portion", $87 \%$ are women and, out of these, only $21 \%$ are "head of household".${ }^{7}$ Regarding the unemployed who receive $\mathrm{AUH}, 8.9 \%$ of them are the main contributor to the household, although not necessarily the only one. The beneficiary population is mostly the poor: $70.4 \%$ in national average, and reaching $81 \%$ in regions such as the North of the country.

AUH recipients are mostly women (97\%). There were two resolutions in 2009 and 2013 that gave preference to mothers before fathers. This can be explained based on a set of gender inequalities that start with a huge inequality in household chores: $75 \%$ are performed by women (Shokida 2019). The income gap between men and women is $26 \%$. Women face worse working conditions: $37 \%$ of working women have an unregistered job, and the wage gap reaches $37 \%$. Almost all people (97.6\%) who work in domestic service are women. This is a key source of employment for them. In fact, $17 \%$ of female workers are engaged in this area. Finally, income distribution is affected: within the poorest $10 \%, 7$ out of 10 people are women (Shokida 2019).

AUH is a policy to increase income, which was implemented as an adjustment to the reality of the labor market that we described above, dominated by a largely informal economy and labor informality, as well as by low wages, leaving an important part of the employed population below the poverty line.

The AUH should be considered a transfer monetary policy since it is inserted in this process of a more long-range - organic - process that is based on the sustained increase in the surplus population and the consolidation of strength of remunerated work below its value. Thus, the AUH can be seen as a particular expression of the welfare process of the social policy, which responds to the state's strategic objective of containment of the poor population and maintenance of productive attributes at a minimum for its occasional use by capital. (Fernández 2015, 14)

Finally, we have to include in this analysis that the tax system is increasingly regressive, and this includes ANSES. It is necessary to consider the way in which this policy is financed. The studies of Fernández show that:

\footnotetext{
${ }^{5}$ As of 2011, the AUH was complemented by the Asignación Universal por Embarazo (AUE), to future mothers who were in the twelve or more weeks of gestation.

${ }^{6}$ All the official information can be seen at Datos abiertos ANSES (Open information). Available from: https://www.anses.gob.ar/institucional/datos-abiertos

${ }^{7}$ According to Seiffer (2015), these numbers contribute to show that the labor market offers worse conditions for women workers than for men and, on the other hand, that many working women decide to be "housewives", not because they do not need to be employed, but because it is more profitable to save the cost of caring for children and the elderly.
} 
Working class contributes to (...) $52.0 \%$ of the total of the AUH. Bourgeoisie contributes $19.5 \%$ of the total financing to the benefit, while the petite-bourgeoisie contributes $5.5 \%$ of the total. The contribution of the State gain is $5 \%$, rising to higher levels in the case of the contribution of international credit agencies, which do not reach $1 \%$ of the benefit. (Fernández 2015, 42)

This means that employers save expenses necessary for the child support, i.e. for the reproduction of the working class, who itself mostly supports this policy through direct contributions and taxes. Yet the expending in AUH doesn't represent a great burden for the State, since, although the assistant policies expenditure has visibly expanded in the last decades, its weight in the whole public expenditure represents $3.5 \%$ of the total expenditure and less than $1 \%$ of GDP.

\section{The role of the State and Economic and Social Rights precariousness}

As said before, according to various authors, the MPs and the AUH would have inaugurated a new stage for social policies in Argentina, a "broad social protection" model, which has incorporated large sectors of the population that were not registered, in addition to the registered sector. Instead, other authors conclude that, although differences can be recognized with the previous period, there is no evidence of a shift of paradigm (Fernández 2015, Seiffer 2015, Brown 2017, Logiudice 2017, among others). In any case, these two important welfare policies were born within a longer historical process marked by obstacles in the process of capital accumulation (Wainer 2018), the deterioration and segmentation of the labor market (Graña 2015), the long trend to rundown of wages and the working class fragmentation (Iñigo Carrera 2017), and the dependency of economic cycles (Kennedy 2015, Arakaki and Seiffer 2019).

At least in Argentina the so-called "crisis of welfare state" (Isuani 1991) and the change on welfare policies strategies do not seem to have meant the "withdrawal" of the State (Isuani 2010). The public expenditure, that had expanded in the ' 80 s and ' 90 s, registered an average that exceeded 40 percent of the GDP in the last decade, mainly explained by social security, education, and health, which systems are mostly public, and then by public debt and subsidies. Argentina shares the first place with Brazil regarding total public expenditure and it has the highest public expenditure in Social Protection (Cetrángolo and Curcio 2018). "Beneficiaries" of the social security system (retirees and pensioners) are the most numerous mass of workers whose income comes mostly from public funding. They have multiplied in the last 15 years (from 3.5 million to 7 million). Families covered by assistance programs (about 5 million beneficiaries) have also multiplied. Public employment is another transverse phenomenon of the era. In 1970 there were 1.3 million public employees, while in 2019 they were more than 3.9 million. The period after the 2001-2002 crisis until 2013 was the one where public employment grew the most in the whole national history (about 1.5 million new public employees were incorporated, almost $40 \%$ of the 3.9 million total jobs created). This growth was carried out mainly in provinces and municipalities, where wages are low with significant levels of precariousness.

Currently the federal, state and local governments directly pay salaries to 3.6 million employees. ANSES pays pensions and social benefits to another 16 million people. Taking provincial pensioners, retired and pensioners from the Armed Forces, Police and Security Forces into account, as well as social plans and employment plans, around 
another 1.5 million people receive benefits. In December 2002 there were 8.7 million people supported in total or partially by the State; in 2009 there were almost 11 million; in 2019 there were over 21 million people, nearly half of the Argentinian population.

\section{FIGURE 1}

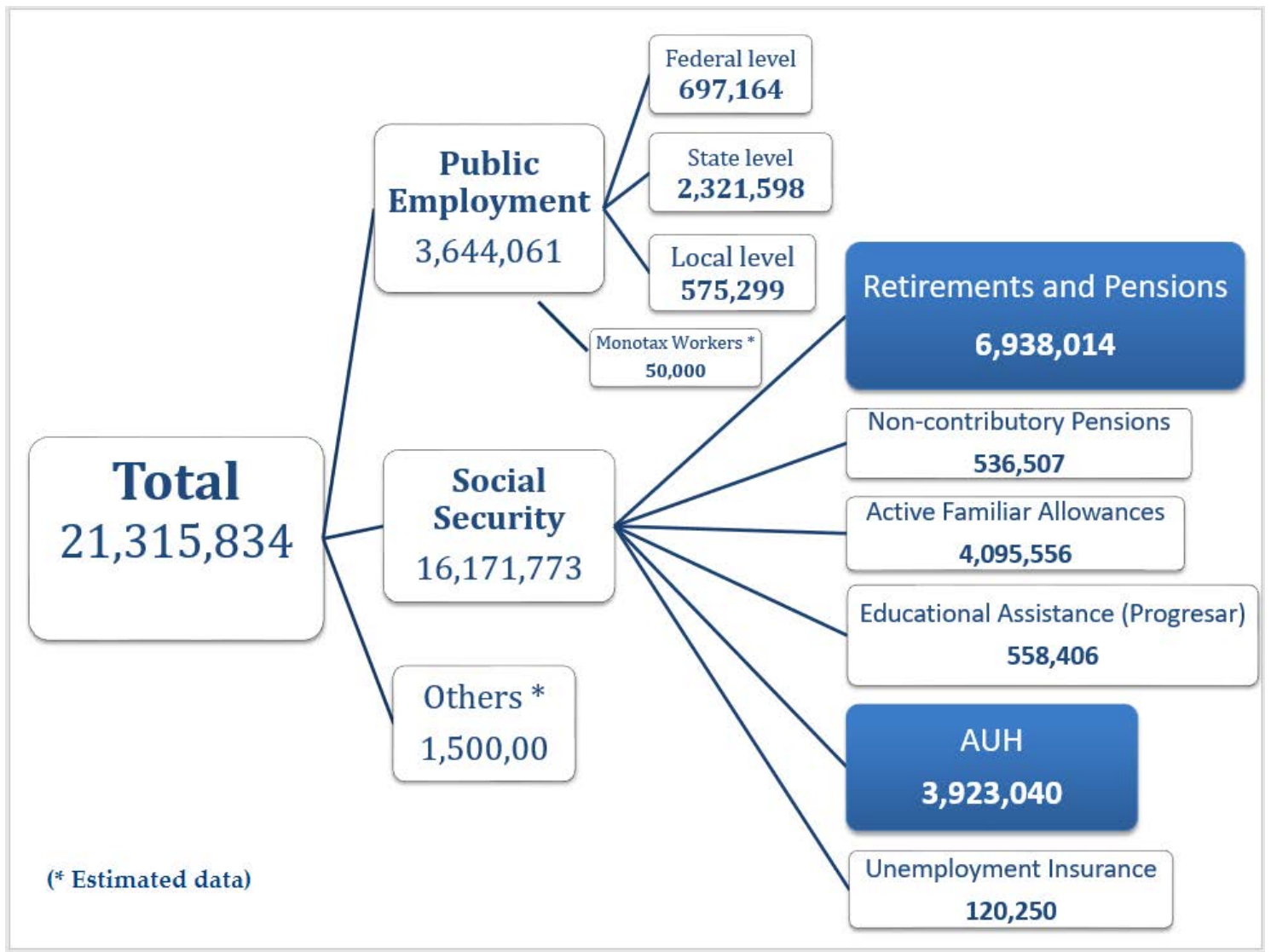

Figure 1. People with income dependent on the State in Argentina.

(Source: Data compiled by the author based on Ministerio de Trabajo and ANSES's official websites.)

Apart from having focused on social policies recipients, it is must to be said that the increasing capacity of mediation of the State does not only involve the working class but also capitalists. Public spending on "debt services" (which for a long time has mostly gone to pay off interest of public debt to foreign and local creditors) and on "economic services" (subsidies to individual capitals) have been important in the analyzed period. Subsidies have been supporting industrial capital by guaranteeing profit rates and, at the same time, have contained the fees of the services (transport, electricity, gas, etc.) that the working class consumes. Salaries are then shaped considering these low prices, allowing employers to buy the labor force cheaper. Finally, it is necessary to keep in mind the cost of maintaining the financial system, which has been very high in the last years.

Moreover, when the budgetary system is analyzed as a whole, it is possible to see a huge mediation of the State in a process of redistribution of wealth among popular sectors, because they are mostly both its contributors and beneficiaries. The State appears as the guarantor of the reproduction of an important mass of the working class, even when public answers are mostly precarious, with sources that primarily come from the working class itself. But then it is also essential to take into account the role of the State as "regulator of economic action" (Garland 2016), as an actor and guarantor of the 
evolution of the conditions under which the labor force is sold and, more generally, of the conditions of the reproduction of the working class.

Considering the three conceptions associated with the idea of welfare state (EspingAndersen 1990, Garland 2016, van der Berg et al. 2017), its development in Argentina has been contradictory. The historical public structure that guarantees basic social services (public health, social security, and education) has expanded in the last decades, manifested in the growth of the social expenditure, as well as the protection policies toward the most vulnerable sectors. In both cases the expansion has mostly been in terms of coverture, but not in quality. Regarding the economic and labor market policies, the state has participated in the development of a process of degradation, fragmentation and heterogeneity of a labor market that had shown signs of strength until the mid-1970s.

Looking at the process in its entirety, the increasing state intervention seems to have been a necessity for the reproduction of the capital accumulation, based essentially on the widespread weakening of the workforce. The intensity of precariousness and its manifestations have been different according to the cycles of expansion or contraction and strategies of accumulation, but it has been a trend that seems to be consolidated.

\section{Final comments}

The main goal of this article has been to contribute to the debates on the role of the State and economic and social rights in Argentina, by proposing an analysis that links the capital accumulation process and the different expressions of the intervention of the State, highlighting the main elements that we should take into account to think about the past, present and future of Human Rights in Argentina, and considering the main welfare policies adopted in the last years in that context.

We have firstly considered some debates on the role of the State and economic and social rights, taking a deeper look at Human Rights-Based approaches, based on their importance in the legal field. HRBAs have focused on the intervention of the state in its "redistributive" role through social policies, especially those protection policies for the most vulnerable sectors, claiming that the State fails in its duty to protect human rights, but without paying enough attention to the evolution of the Argentinian capital accumulation process. We pointed out the necessity to take into account that process, which has undergone significant changes in the last decades, and the role of the State through economic policies, such as regulatory, fiscal, monetary, and labor-market policies.

We have also offered an analysis of the evolution of the Argentinian capital accumulation process in the last decades based on specialized literature and our own previous research projects. To better understand the role of the State in that process we have taken into account some aspects that are not usually considered in studies of economic and social rights, such as government's regulatory, fiscal, monetary, and labormarket policies. In recent decades, Argentina has experienced a process of deep structural transformations that has had a visible impact on the reproductive conditions of the population. While the capital accumulation process has weakened, and the old mechanisms of compensation have become insufficient, the different economic schemes adopted since the ' 70 s converged in the strategy of seeking a growing source of 
compensation in the purchase of the labor force below its value, the trend of deterioration of real wages becoming a very important phenomenon.

Other important changes were added to this trend toward the degradation of the labor market: the increasing expansion of public debt and fiscal deficit, the growth of public expenditure, and the development of a regressive fiscal system, among others. These changes have involved essential macroeconomic and labor market policies (both through active policies or shortcomings), and afterwards have strongly determined the capacity, shapes and contents of state responses to fulfill economic and social rights.

We have seen that since the ' 80 s the State has increased in size, expressed in the growth of public expenditure and fiscal pressure, the extension of welfare policies, public employment, and different ways of "redistribution of income". As a consequence, the mass of the population who depends (at least partially) on public incomes has expanded. Although the PMs have shown better results to fight poverty, both specific welfare policies analyzed herein (the $\mathrm{AUH}$ and the PMs) have been widespread policies as regards the number of beneficiaries, but they have exhibited a precarious form (in terms of recognition of rights) and content (their economic capacity).

We have highlighted the link between the deterioration of the labor market and the expansion of social policies and public employment. The results have not been favorable for the working-class living conditions. On the one hand, the gaps in the quality of employment have worsened, and there is a widely extended micro-informal subsistence sector (social economy) of very low productivity and high precariousness. On the other hand, while currently almost half of the Argentine population receives income from the State, poverty levels remain very high: $40 \%$ of the population and almost $60 \%$ of children live below the poverty line, measured both in terms of income and in structural terms, and are deprived of a set of rights.

Looking at the process as a whole, this impoverishment of the working population seems to have been a condition for the reproduction of the capital accumulation. So it is quite difficult to imagine that this process entails the fulfillment of the rights of the population to the fullest through welfare policies given that even the reproduction of many actively working people below their needs is a condition for its own reproduction. Conversely, the precariousness of the State responses through social policies seems to fit with that requirement. Therefore, given this outlook we are required to go into more detail about the structural problems around the fulfillment of economic and social rights in an attempt to provide more enlightening insights.

\section{References}

Abramovich, V., 2006. Una aproximación al enfoque de derechos en las estrategias y políticas de desarrollo. Revista Cepal [online], 88, 35-50. Available from: https://repositorio.cepal.org/bitstream/handle/11362/11102/088035050 es.pdf?seq uence $=1 \&$ isAllowed $=y$ [Accessed 15 January 2020].

Adriani, H., 2011. Transformaciones del sector industrial argentino en las últimas décadas. Estudio de caso de sus impactos territoriales. Revista Geográfica De América Central [online], 2(47E), 1-15. Available from: 
https://www.revistas.una.ac.cr/index.php/geografica/article/view/2094 [Accessed 15 January 2020].

Alonso, G., and Di Costa, V., 2011. Cambios y continuidades en la política social argentina, 2003-2010. Presentation at the VI Congreso Argentino de Administración Pública. Resistencia, Chaco. July.

Alvaredo, F., Cruces, L., and Gasparini, L., 2018. A short episodic history of income distribution in Argentina. Latin American Economic Review [online], 27(Feb.), Art. $\mathrm{n}^{\mathrm{o}}$ 7, 1-45. Available from: https://doi.org/10.1007/s40503-017-0048-3 [Accessed 15 January 2020].

Álvarez, L., and Bonnet, A., 2017. Ensayo y error: Un análisis marxista de las políticas públicas. Revista Mexicana de Ciencias Políticas y Sociales [online], no 233, 169-192. Available from: http://www.scielo.org.mx/pdf/rmcps/v63n233/0185-1918-rmcps63-233-169.pdf [Accessed 15 January 2020].

Arakaki, A., and Seiffer, T., 2019. Pobreza. In: I. Llovet and P. Scarponetti, eds., Estudio sobre condiciones de vida en la Argentina contemporánea. Buenos Aires: CLACSO, 217-259.

Arcidiácono, P., and Gamallo, G., 2011. Política social y judicialización de los derechos sociales. Temas y Debates [online], $\mathrm{n}^{\mathrm{o}}$ 22, 65-85. Available from:

https://core.ac.uk/download/pdf/61699898.pdf [Accessed 15 January 2020].

Arza, C., 2009. Back to the state: Pension fund nationalization in Argentina. Documentos de Trabajo del CIEPP, 73, 1-53.

Arza, C., 2012. Extending coverage under the Argentinian pension system: Distribution of access and prospects for universal coverage. International Social Security Review [online], 65(2), 29-49. Available from: https://doi.org/10.1111/j.1468246X.2011.01427.x [Accessed 15 January 2020].

Arza, C., and Chahbenderian, F., 2014. Pensiones básicas en América Latina: Diseño, cobertura y beneficios comparados en Argentina, Brasil, Bolivia y Chile.

Documentos de Trabajo del CIEPP [online], 89, 1-49. Available from:

https://ri.conicet.gov.ar/handle/11336/35169 [Accessed 15 January 2020].

Asociación Civil por la Igualdad y la Justicia, 2018. Alternativas a la austeridad fiscal: políticas fiscales con enfoque de derechos [online]. Buenos Aires, May. Available from: https://acij.org.ar/hay-alternativas-a-la-austeridad-fiscal-politicas-fiscales-conenfoque-de-derechos-los-paises-latinoamericanos-deben-reformar-sus-politicasfiscales-para-garantizar-los-derechos-humanos/ [Accessed 15 January 2020].

Barrientos, A., 2012. Dilemas de las políticas sociales latinoamericanas. ¿Hacia una protección social fragmentada? Revista Nueva Sociedad [online], no 239, (May/Jun), 65-78. Available from: https://nuso.org/articulo/dilemas-de-las-politicas-socialeslatinoamericanas-hacia-una-proteccion-social-fragmentada/ [Accessed 15 January 2020].

Basualdo, E., 2006. Estudios de Historia Económica argentina: Desde mediados del siglo XX a la actualidad. Buenos Aires: FLACSO / Siglo XXI. 
Basualdo, V., and Morales, D., 2014. La tercerización laboral: Orígenes, impacto y claves para su análisis en América Latina. Buenos Aires: Siglo XXI.

Behm, L., and Cristeche, M., 2017. Las políticas sociales y su repercusión en el sistema de derechos Marco jurídico, jurisprudencia y principales programas en Argentina (2003-2015). Revista Derechos en Acción [online], no 2, 125-141. Available from: http://sedici.unlp.edu.ar/bitstream/handle/10915/59575/Documento completo.pdf -PDFA.pdf?sequence=1\&isAllowed=y [Accessed 15 January 2020].

Bertranou, F., and Casanova, L., 2017. Employment formalization in Argentina: Recurring and new challenges for public policies. In: C. Fenwick and V. van Goethem, eds., Regulating for Equitable and Job-Rich Growth [online]. Cheltenham: Edward Elgar, 173-194. Available from: https://doi.org/10.4337/9781788112673.00016 [Accessed 15 January 2020].

Bertranou, F., et al., 2013. Informalidad, calidad del empleo y segmentación laboral en Argentina [online]. Working Paper. September. Buenos Aires: Oficina de País de la OIT para la Argentina. Available from: https://www.ilo.org/wcmsp5/groups/public/---americas/---ro-lima/---ilobuenos aires/documents/publication/wcms 228741.pdf [Accessed 15 January 2020].

Bossert, C.F., 2016. Alianzas, poder y política social en Argentina. Revista de Ciencias Sociales [online], no 151, (Jan/Mar), 111-125. Available from: https://doi.org/10.15517/rcs.v1i151.24973 [Accessed 15 January 2020].

Brown, B., 2017. Sistema de Protección social y Programas de Transferencias Monetarias Condicionadas. El "paradigma de activación" en Argentina 20032013. Documentos de Trabajo del CIEPP [online], no 99, 1-47. Available from: http://www.ciepp.org.ar/index.php/documentosdetrabajo1/476-documentos-99 [Accessed 15 January 2020].

Cachanosky, N., 2017. Reflexiones sobre la economía argentina. Buenos Aires: Instituto Acton.

Caligaris, G., 2017. Los países productores de materias primas en la unidad mundial de la acumulación de capital: un enfoque alternativo. Cuadernos de Economía Crítica [online], 06, 15-43. Available from: https://cicpint.org/es/caligaris-g-2017-lospaises-productores-de-materias-primas-en-la-unidad-mundial-de-laacumulacion-de-capital-un-enfoque-alternativo-cuadernos-de-economia-critica06-15-43/ [Accessed 15 January 2020].

Cazón, F., et al., 2017. Contribuciones al debate sobre el rol del salario real en la acumulación de capital en Argentina. Evidencias en torno a la venta de la fuerza de trabajo por debajo de su valor. Ciclos en la historia, la economía y la sociedad [online], no 49, 1-14. Available from: https://ojs.econ.uba.ar/index.php/revistaCICLOS/article/view/1244 [Accessed 15 January 2020].

Centro de Investigación y Formación de la República Argentina, 2009. La evolución del sistema previsional argentino [online]. Working paper $\mathrm{n}^{\circ}$ 2. September. Available 
from: http://www.aaps.org.ar/pdf/area politicassociales/Basualdo.pdf [Accessed 15 January 2020].

Cetrángolo, O., and Curcio, J., 2018. El gasto público en América Latina y el Caribe durante los últimos 30 años. LIII Reunión Anual. Anales [online]. November. Asociación Argentina de Economía Política, 1-47. Available from: https://aaep.org.ar/anales/works/works2018/cetrangolo.pdf [Accessed 15 January 2020].

Comisión Económica para América Latina y el Caribe, 2012. Informe macroeconómico de América Latina y el Caribe [online]. NU. CEPAL. División de Estadística y Proyecciones Económicas. June. Available from: https://www.cepal.org/es/publicaciones/1118-informe-macroeconomico-americalatina-caribe-junio-2012 [Accessed 15 January 2020].

Cortés, R., and Marshall, A., 1991. Estrategias económicas, intervención social del Estado y regulación de la fuerza de trabajo (1890-1990). Estudios del Trabajo [online], 1, 21-46. Available from: http://publicacioneseconomia.flacso.org.ar/images/pdf/249.pdf [Accessed 15 January 2020].

Cristeche, M., 2013. Estado, relaciones jurídicas públicas y reproducción social en Argentina: acumulación de capital y gasto público estatal (1980-2010). PhD Thesis. Buenos Aires: Catálogos UBA.

Cristeche, M., and Muñoz, P., 2019. Sistema previsional y modelación de los derechos de la vejez en Argentina (2003-2017). Revista de Derecho [online], nº 52, 13-36.

Available from: http://rcientificas.uninorte.edu.co/index.php/derecho/article/viewFile/11046/2144 21444348 [Accessed 15 January 2020].

Damill, M., Frenkel, R., and Rapetti, M., 2015. Macroeconomic Policy in Argentina during 2002-2013. Comparative Economic Studies [online], 57(3), 369-400. Available from: https://doi.org/10.1057/ces.2015.3 [Accessed 15 January 2020].

Danani, C., 2004. Política social y economía social: Debates fundamentales. Buenos Aires: Altamira.

Diéguez, G., and Gasparin, J., 2016. El rompecabezas del empleo público en Argentina: Quiénes hacen funcionar la maquinaria del Estado. Dcoumento de Politicas Públicas [online] CIPPEC. Available from: https://www.cippec.org/wpcontent/uploads/2017/03/1082.pdf [Accessed 15 January 2020].

Esping-Andersen, G., 1990. The Three Worlds of Welfare Capitalism. Princeton University Press.

Falappa, F., and Andrenacci, L., 2009. La política social de la Argentina democrática (19832008). Los Polvorines: Universidad Nacional de General Sarmiento.

Faleiros, V.d.P., 2000. Las funciones de la política social en el capitalismo. Sao Paulo: Cortez.

Fernández, E., 2015. ¿Quiénes sostienen a la población pobre en la Argentina actual? Un ejercicio de análisis sobre el financiamiento de la Asignación Universal por Hijo. PIMSA Documentos y comunicaciones, 15, 9-52. 
Ferreres, O., 2011. Dos siglos de economía argentina. Buenos Aires: Fundación Norte y Sur.

Fraschina, S., 2019. Salario en Argentina [online]. Universidad Nacional de Avellaneda: Observatorio de Políticas Públicas. Available from: http://undav.edu.ar/index.php?idcateg=198 [Accessed 15 January 2020].

Gaggero, A., 2008. "Fui industrial durante muchos años": Los Grupos Económicos Nacionales y el proceso de extranjerización del empresariado argentino durante la década de los noventa. Papeles de Trabajo, 2(3), 138-159.

Gaggero, A., Schorr, M., and Wainer, A., 2014. Restricción eterna: El poder económico durante el kichnerismo. Buenos Aires: Futuro Anterior.

Gaggero, J., 2008. La cuestión tributaria en Argentina: el caso de un retroceso histórico. Ciclos [online], 17(33-34), 215-237. Available from:

http://bibliotecadigital.econ.uba.ar/download/ciclos/ciclos v17 n33-34 09.pdf [Accessed 15 January 2020].

Garland, D., 2016. The Welfare State: A Very Short Introduction [online]. Oxford University Press. Available from: https://doi.org/10.1093/actrade/9780199672660.001.0001 [Accessed 15 January 2020].

Garriz, A.I., et al., 2012. Trabajadores pobres en Argentina. Empleo, desempleo y políticas de empleo [online], no 12, 1-69. Available from: http://www.ceil-conicet.gov.ar/wpcontent/uploads/2013/07/edpe12.pdf [Accessed 15 January 2020].

Giménez Mercado, C., and Valente Adarme, X., 2010. El enfoque de los derechos humanos en las políticas públicas: ideas para un debate en ciernes. Cuadernos del CENDES, $\mathrm{n}^{\mathrm{o}} 74,51-80$.

Graña, J., 2015. Evolución comparada del sector industrial argentino y estadounidense, entre el rezago productivo y el deterioro salarial. H-Industri@ [online], 17(9), 3463. Available from: http://ojs.econ.uba.ar/ojs/index.php/H-ind/article/view/839 [Accessed 15 January 2020].

Graña, J., 2018. Labor market trends in a low and heterogeneous productivity country. Evidence from Argentina's manufacturing. Brazilian Journal of Political Economy [online], 38(2), 358-376. Available from: https://doi.org/10.1590/010131572018v38n02a08 [Accessed 15 January 2020].

Graña, J., and Kennedy, D., 2017. Rezago productivo y sus fuentes de compensación: la vigencia de los limitantes estructurales del ciclo económico argentino al comienzo del siglo XXI. Cuadernos del CENDES [online], 95(34), 91-116. Available from: https://ri.conicet.gov.ar/handle/11336/72742 [Accessed 15 January 2020].

Grassi, E., 2003. Políticas y problemas sociales en la sociedad neoliberal: La otra década infame. Buenos Aires: Espacio.

Grassi, E., and Danani, C., 2009. El mundo del trabajo y los caminos de la vida. Buenos Aires: Espacio. 
Grosman, L., 2008. Escasez e igualdad: Los derechos sociales en la Constitución. Buenos Aires: Libraria.

Grushka, C., Gaiada, C., and Calabria, A., 2017. Sistema(s) previsional(es) en la Argentina y cobertura: análisis de las diversas fuentes de datos y de los diferenciales por edad, sexo y jurisdicción [online]. Administración Nacional de la Seguridad Social. Available from:

https://www.researchgate.net/publication/315782048 Sistemas previsionales en la Argentina_y cobertura analisis de las diversas fuentes de datos_y de los diferenciales por edad sexo y jurisdiccion [Accessed 15 January 2020].

Holmes, S., and Sunstein, C., 2000. The Cost of Rights: Why Liberty Depends on Taxes. New York: W.W. Norton \& Company.

Iamamoto, M., 1997. Servicio social y la división del trabajo. Sao Paulo: Cortez.

Iñigo Carrera, J., 2006. Argentina: The Reproduction of Capital Accumulation through Political Crisis. Historical Materialism [online], 14(1), 185-219. Available from: https://doi.org/10.1163/156920606776690884 [Accessed 15 January 2020].

Iñigo Carrera, J., 2007. La formación económica de la sociedad argentina. Volumen 1: Renta agraria, ganancia industrial y deuda externa. 1882-2004. Buenos Aires: Imago Mundi.

Iñigo Carrera, J., 2017. La renta de la tierra: Formas, fuentes y apropiación. Buenos Aires: Imago Mundi.

Instituto Nacional de Estadísticas y Censo, 2018. EPH: Evolución de la Distribución del Ingreso. Informes técnicos [online], 2(243). Available from:

https://www.indec.gob.ar/uploads/informesdeprensa/ingresos 3trim18.pdf [Accessed 15 January 2020].

Instituto para el Desarrollo Social Argentino, 2018. 9 de cada 10 trabajadores pobres no están sindicalizados. Informe [online], no 779. Available from: https://idesa.org/9de-cada-10-trabajadores-no-estan-sindicalizados/ [Accessed 15 January 2020].

Isuani, E., 1991. Bismarck o keynes: ¿Quién es el culpable? Notas sobre la crisis de acumulación. In: E. Isuani, R. Lo Vuolo and E. Tenti Fanfani, eds., El Estado benefactor: Un paradigma en crisis. Buenos Aires: Miño y Dávila / CIEPP, 6-19.

Isuani, E., 2010. The Argentine welfare state: enduring and resisting change. International Journal of Social Welfare [online], 19(1), 104-114. Available from: https://doi.org/10.1111/j.1468-2397.2009.00642.x [Accessed 15 January 2020].

Joshi, Y., 2009. What's wrong with human rights? The Guardian [online], 9 October. Available from:

https://www.theguardian.com/commentisfree/libertycentral/2009/oct/09/humanrights [Accessed 15 January 2020].

Kennedy, D., 2002. The Critique of Rights in Critical Legal Studies. In: W. Brown and J. Halley, eds., Left Legalism/Left Critique. Durham: Duke University Press, 178-228.

Kennedy, D., 2007. El lado oscuro de la virtud. Madrid: Almuzara.

Kennedy, D., 2014. Producción y apropiación del valor en Argentina: el rol del deprimido salario real. Problemas del Desarrollo [online], 45(176), 157-182. 
Available from: https://doi.org/10.1016/S0301-7036(14)70854-5 [Accessed 15 January 2020].

Kennedy, D., 2015. Las fuentes de compensación desde la perspectiva de la contabilidad social y su rol en el ciclo económico. Convertibilidad y postconvertibilidad en perspectiva histórica. In: J. Lindenboim and A. Salvia, eds., Hora de balance: Proceso de acumulación, mercado de trabajo y bienestar. Argentina 2002-2014. Buenos Aires: Eudeba, 75-107.

Kennedy, D., 2018. Debates en torno a las condiciones actuales de reproducción de la fuerza de trabajo argentina en perspectiva histórica. Universidad de Buenos Aires, Facultad de Ciencias Económicas.

Kennedy, D., and Sánchez, M., 2019. Drenaje de divisas y endeudamiento público externo. El balance de pagos argentino: 1992-2018. Realidad Económica [online], 48(322), 9-40. Available from: https://ojs.iade.org.ar/index.php/re/article/view/48 [Accessed 15 January 2020].

Kornblihtt, J., and Dachevsky, F., 2010. De una crisis a otra. Devaluación, conflicto agrario y límites de la acumulación de capital en Argentina (2002-2008). Revista Venezolana de Análisis de Coyuntura [online], 16(1), 165-185. Available from: https://www.redalyc.org/articulo.oa?id=36415689008 [Accessed 15 January 2020].

Kornblihtt, J., Seiffer, T., and Mussi, E., 2016. Las alternativas al neoliberalismo como forma de reproducir la particularidad del capital en América del Sur. Pensamiento al margen [online], $\mathrm{n}^{\mathrm{o}}$ 4, 104-135. Available from: https://cicpint.org/es/kornblihtt-jseiffer-t-mussi-e-2016-las-alternativas-al-neoliberalismo-como-forma-dereproducir-la-particularidad-del-capital-en-america-del-sur-pensamiento-almargen-4-104-135/ [Accessed 15 January 2020].

Kornblihtt, J., Seiffer, T., and Villanova, N., 2014. De la caída relativa a la caída absoluta del salario real en la Argentina (1950- 2013). Revista Científica Guillermo de Ockham [online], 12(2), 41-50. Available from:

https://dialnet.unirioja.es/descarga/articulo/6456377.pdf [Accessed 15 January 2020].

Logiudice, A., 2017. La política social asistencial argentina y el nuevo escenario político. Las incipientes transformaciones del gobierno de "Cambiemos" [online]. Paper presented at IX Congreso Latinoamericano de Ciencia Política, ALACIP. Montevideo, 26-28 July. Available from:

http://www.congresoalacip2017.org/arquivo/downloadpublic2?q=YToyOntzOjY6 InBhcmFtcyI7czozNToiYToxOntzOjEwOiJJRF9BUlFVSVZPIjtzOjQ6IjI2MzIiO30i O3M6MToiaCI7czozMjoiZWZhODYxZWI2YjdkOGY3MzZiNDhhNDhjMmYyMj hjYjYiO30\%3D [Accessed 15 January 2020].

Matusevicius, J., and Seiffer, T., 2010. Formas de la sobrepoblación relativa y políticas sociales. La política asistencial durante el primer gobierno kirchnerista (20032007). Razón y Revolución, 20, 109-123.

Mazzola, R., 2014. Nuevo paradigma: la Asignación Universal por Hijo en Argentina. Buenos Aires: Prometeo. 
Micha, A., and Trombetta, M., 2018. Protección social y movilidad del ingreso: la AUH como estabilizador. LIII Asociación Argentina de Economía Política, Anales [online]. November. Available from: https://aaep.org.ar/anales/works/works2018/micha.pdf [Accessed 15 January 2020].

Moro, G., 2011. La posibilidad de un derecho constitucional a la alimentación. In: R. Gargarella, ed., La Constitución en 2020. Buenos Aires: Siglo XXI.

Moyn, S., 2012. The Last Utopia: Human Rights in History [online]. Cambridge, MA: Harvard University Press. Available from: https://doi.org/10.2307/j.ctvjk2vkf [Accessed 15 January 2020].

Moyn, S., 2018. Not Enough: Human Rights in an Unequal World [online]. Cambridge, MA: Harvard University Press. Available from: https://doi.org/10.4159/9780674984806 [Accessed 15 January 2020].

Netto, J.P., 1992. Capitalismo monopolista y servicio social. Sao Paulo: Cortez.

O'Connell, P., 2017. Marxism and Human Rights. Legal Form. A forum for Marxist Analysis of Law [online], 25 November. Blog post. Available from: https://legalform.blog/2017/11/25/marxism-and-human-rights-paul-oconnell/ [Accessed 15 January 2020].

Observatorio de Políticas Sociales, 2019. La deuda argentina [online]. Report. May. Available from: http://undav.edu.ar/general/recursos/adjuntos/23792.pdf [Accessed 15 January 2020].

OCDE et al., 2019. Estadísticas tributarias en América Latina y el Caribe [online]. Available from: https://www.oecd.org/tax/tax-policy/brochure-estadisticas-tributarias-enamerica-latina-y-el-caribe-2019.pdf [Accessed 15 January 2020].

Pautassi, L., 2010. Perspectiva de derechos, políticas públicas e inclusión social: Debates actuales en la Argentina. Buenos Aires: Biblos.

Pautassi, L., 2015. Los derechos en las políticas sociales: Desafíos teóricos y opciones estratégicas. Debate Público [online], 10, 43-60. Available from: https://ri.conicet.gov.ar/handle/11336/70256 [Accessed 15 January 2020].

Pautassi, L., and Gamallo, G., eds., 2012. ¿Más derechos, menos marginaciones? Políticas sociales y bienestar en la Argentina. Buenos Aires: Biblos.

Pautassi, L., Arcidiácono, P., and Straschnoy, M., 2014. Condicionando el cuidado: la asignación universal por hijo para la protección social en Argentina. Íconos, Revista de Ciencias Sociales [online], 50, 61-75. Available from: https://doi.org/10.17141/iconos.50.2014.1429 [Accessed 15 January 2020].

Peralta Ramos, M., 2007. La economía política argentina: poder y clases sociales. Buenos Aires: Fondo de Cultura Económica.

Peralta Ramos, M., and Waisman, C., 2018. From military rule to liberal democracy in Argentina [online]. New York: Routledge. Available from: https://doi.org/10.4324/9780429038372 [Accessed 15 January 2020]. (Originally published in 1987). 
Proyecto Económico, 2019. Perdones Impositivos [online]. Executive Report. 15

November. Available from: http://proyectoeconomico.com/wp-

content/uploads/2019/12/Perdones-impositivos.pdf [Accessed 15 January 2020].

Rapoport, M., 2011. Una revisión histórica de la inflación argentina y de sus causas. In:

J. Vázquez Blanco and S. Fraschina, eds., Aportes de la Economía Política en el Bicentenario. Buenos Aires: Prometeo, 135-165.

Salvia, A., 2019. Pobreza de ingresos en la Argentina de ayer y de hoy: La manifestación de un problema estructural [online]. Presentation at Seminario UCA-PNUD, 22 October.

Available from:

http://wadmin.uca.edu.ar/public/ckeditor/Observatorio\%20Deuda\%20Social/Pres entaciones/2019/2019-OBSERVATORIO-SEMINARIO-CICLOS-ODSA-PNUDSALVIA.pdf [Accessed 15 January 2020].

Salvia, A., and Lindenboim, J., 2015. Hora de Balance: Proceso de Acumulación, mercado de trabajo y bienestar. Argentina 2002-2014. Buenos Aires: Eudeba.

Seiffer, T., 2013. Bases de la asistencialización de la Política Social en Argentina (19802010). Documentos de Trabajo Social, 51, 69-88.

Seiffer, T., 2015. Asignación Universal por Hijo y PROGRESAR: ¿un cambio en la forma estatal de atendimiento de la "cuestión social" en Argentina? In: A. Rossi et al., eds., Política asistencial, programas de transferencias monetarias condicionadas y organismos internacionales de crédito en América Latina y el Caribe. La Plata:

Dynamis, 267-299.

Seiffer, T., 2019. Acumulación de capital y condiciones de vida de la clase obrera en perspectiva histórica. In: M. Martínez Reina, ed., La estructura social argentina, condiciones de empleo y organización de los trabajadores sociales. La Plata: Instituto de Capacitación y Estudios Profesionales / CATSPBA, 9-15.

Seiffer, T., and Rivas Castro, G., 2017. La política social como forma de reproducción de la especificidad histórica de la acumulación de capital en Argentina (2003-2016). Estudios del Trabajo [online], 54, 91-117. Available from: https://cicpint.org/es/seiffer-t-rivas-castro-g-2017-la-politica-social-como-formade-reproduccion-de-la-especificidad-historica-de-la-acumulacion-de-capital-enargentina-2003-2016-estudios-del-trabajo-54-9/ [Accessed 15 January 2020].

Shokida, N., 2019. La desigualdad de género se puede medir. Economiafemini(s)ta [online], 3 March. Blog post. Available from: http://economiafeminita.com/ladesigualdad-de-genero-se-puede-medir-3/ [Accessed 3 April 2019].

van den Berg, A., et al., 2017. Combating poverty: Quebec's pursuit of a distinctive welfare state. University of Toronto Press.

Wainer, A., 2018. Economía y política en la Argentina kirchnerista (2003-2015). Revista Mexicana de Sociología [online], no 80, 323-351. Available from:

http://www.scielo.org.mx/pdf/rms/v80n2/0188-2503-rms-80-02-323.pdf [Accessed 15 January 2020]. 